\title{
A CRITICAL ANALYSIS ON JANE AUSTEN AS A SUPREME MISTRESS OF COMEDY
}

\author{
Ms. Nirupama Patel
}

\begin{abstract}
Among the Victorian women novelists, Jane Austen ranks as a supreme mistress of comedy. Macaulay has boldly compared her with Shakespeare. (Dawson 78). She brought to her task of social comedy a singular combination of rare gifts- wit and satire of wonderful delicacy, a mind of great penetration, a style absolutely pellucid and effortless. No novelist has ever been more thoroughly an artist both in her attitude towards her own work and in her respect for her own limitations. She is so impersonal in her attitude that one may seek in vain for any trace of her own opinions or thoughts in her writings.
\end{abstract}

Key words: Supreme; Combination; Penetration; Attitude.

\section{Jane Austen Painted the World She Knew}

Within her own limits she comes as near perfection as any human genius can, and those who object to the material and scale of her art should recollect that a dewdrop may be as perfect a creation as a star, a grass-blade may be fashioned with as high a skill as the most wonderful of tropic flowers. (Haggerty 96). In order justly to appreciate Jane Austen, the first duty of the reader is, then, quite obvious; it is to respect the limitations of her art, as she herself did. It is foolish to expect from her what she does not profess to give, such as romance, or high-flown sentiment, or the tragedy of great passions. She painted the world she knew; her claim is that she not only painted it with fidelity, but with sympathy; with a lively sense of its blemishes, and with an ever-present satire, no doubt; but also with a true insight into its redeeming pieties and virtues. It is not her fault that romance and sentiment and large passions are not found in her pages; they were not found in the world she knew. Miss Austen wriote as a woman, about women and on themes that are of the first importance to a woman. Her presentation of the masculine mind is confined to the picturing of men as they appear to men. She is acquainted with but a limited number of people.

\section{Feminization in Austen's Novels}

In her novels, therefore, we find ourselves in an intensely feminine atmosphere. She represents a feminization of the English novel and in this respects she stands in sharp contrast with Fielding. Her chief theme is love in the life of woman. The 
beginning of love affair, its progress or its decline, the speculations, jealousies and rivalries, the pleasure, anxiety or triumph of out lookers, the foibles and vanities, on the one hand, and the good qualities on the other, which distinguish women the influence of circumstances and 82 upbringing upon their character all this is admirably delivered. Her novels are essentially love stories. Universal significance of her novels are important reason for her enduring popularity. This universal significance is achieved through two ways. First she creates living characters. She penetrates beneath the surface to the underlying principles of personality.

She has full understanding of human psychology and this enables her to intricate and complex nature. She lays here not only the process of their minds but also those of the heart. All her characters thus become living breathing realities. She considers them impartially and shows them compounded both of faults and virtues like human beings They have a universal significance. Austen represents feminization of English novel. It is a typical woman's point of view that she projects in her novels. She draws her men not perhaps as they are or as they appear to other men, but as they appear to other men, but as they appear to women. Her Darcy and Bingley, Knightly and Churchill are seen through the eyes of her women, Elizabeth, Jane and Emma. The men as a matter of fact, never appear alone; they are always in the company of women, engaged in such activities as women can participate in- ball, dinners, card sessions or just walks.

\section{Jane Austen - A Pure Novelist}

Jane Austen has often been called a pure novelist, which means that her art exits only for art's sake and does not have any other relevance except that it is a source of great aesthetic pleasure on account of its artistic exquisiteness. But her art is not just a source of great delight; it is also the vehicle of her moral vision that being based on common sense is pretty sound. The novel Emma is undoubtedly a comedy, and it is at the same time largely a study of complex personality, namely the personality of the heroine. In other words, this novel combines the interest of a comedy with the deeper interest of a character of a study. The novel as a whole is conceived in a spirit of irony, and the comic interest proceeds chiefly from the use of irony, irony in the incidents and irony in the characterization.

Jane Austen in her novels show her concern about the position of women in the society of her time through the marriage of Jane Fairfax to Frank Churchill. Jane Fairfax, a talented woman, finds that there is no scope for her life except to become a governess. Thus she sees no future before her 83 except by marrying a man who, in a moral and intellectual sense, is not fit for her. A good deal of the moral passion 
of this novel thus arises from the author's feeling about the problems of women in her time. Jane Austen is a humorist. She loves fools and follies for their own sake. Her sense of laughter is so keen that she ridicules even characters like Elizabeth and Emma whom she loves most. Any deviation from good sense and light conduct, anything absurd or incongruous appealed to her sense of the humorous. Folly she ridicules whenever she can. She looks at the manifold follies of her fools with a smile of kindly tolerance. She is never malicious, though she is mischievous at times. She did not despise even the most ridiculous characters like Mrs. Benet and Mr. Collins. She had no reforming zeal.

\section{Jane Austen's Works - Stood the Test of Time}

Jane Austen's works have stood the test of time because of her elegant, graceful prose that depict English middleclass life so beautifully. Her writing contains elements of humor and wit, while her female characters, like Emma, are often strong-willed and articulate. For these reasons, Austen's novels are not only excellent examples of 19th century English women's fiction, but also examples of historical fiction, and early feminist writing before feminism was even named as a movement She is one of the most celebrated writers in English. Though people wrote novels before her, she distilled the form into art, and she defends the novel as an art form in several of her novels, Austen's plots, though fundamentally comic, highlight the dependence of women on marriage to secure social standing and economic security. Her works are concerned with moral issues. Jane Austen is without question, one of England's most enduring and skilled novelists. With her wit, social precision, and unerring ability to create some of literature's most charismatic and believable heroines, she mesmerizes her readers as much today as when her novels were first published. Jane Austen is as sure-footed in her steps through society's whirlpools of convention and prosaic mores as she is in her sometimes restrained but ever precise and enduring prose. Austen's novels are principally concerned with the social fabric of late eighteenth- and early nineteenthcentury England, a patriarchal society in which men held the economic and social power. In an often satirical portrait of 84 the men and women attempting to gain a livelihood, Austen subtly and ironically points out faults in the system, raising questions about the values of English society and the power structure of the country.

Pride and Prejudice contains many elements of social realism, and it focuses on the merging of the bourgeoisie and the aristocracy during the era of the Napoleonic wars and at the beginning of the industrial revolution. The novel is also engaged in an ideological debate that drives its plot and defines the essence of its main character. Interested in the balance between pragmatism, or the necessity of securing a marriage, and idealism, particularly Elizabeth's romanticism and individualism, 
Austen dramatizes her heroine's struggle to find a place within the conservative social institution of marriage. The precise nature of this balance is not necessarily clear, and despite what seems to be a happy marriage, it may not be entirely possible to reconcile Elizabeth's independence and naturalness with Mr. Darcy's conservatism and conventionality It is not merely the fools and snobs and their words and their actions which amuse the readers of Jane Austen's novels. The apparently wise, the self righteous and the virtuous also come in for comic treatment at the novelist's hands. She makes a very effective use of dramatic irony emphasizing the difference between things as they are and things as they appear to be in the eyes of her deluded men and women. The source of our amusement often lies in realizing the inability of the characters to see the situation as it really is and as we and the novelists see it. If we fail to perceive the ironical amusement of Jane Austen's own attitude we will not be able to enjoy much of the humour of her novels. She is highly diverted by human follies and foibles and weaknesses and she is far from being angry or embittered or cynical at discovering what fools we mortals are.

Human absurdities and illusions, so far as they do not lead to tragic consequences ought to please us. They, in fact, make our fellow beings all the more lovable and interesting. Pictures of perfection are likely to be odious, because they are not human and do not belong to this imperfect world of ours, in which Jane Austen and her readers are interested. Many things are not right about the world and its inhabitants, but this only makes them more interesting and lovable. For 85 instance, we see how Emma Woodhouse, who has all along been earnestly trying to improve the minds and fortune of Harriet Smith reacts in quite an unexpected manner at the girl's found assurance that Mr. Knightly took an interest in her. Emma has been in love with Mr. Knightly all the time. We who know the reason for Emma's reaction, feel amused and also pleased because it is the right human reaction. We do not expect her to be a stoic and to work for Harriet's happiness unmindful of her own because like her creator, we are less of moralists and more of humorists. As in many of Austen's other novels, irony is employed in Pride and Prejudice as the lens through which society and human nature are viewed. Through the novel, Austen studies social relationships in the limited society of a country neighborhood and investigates them in detail with an often ironic and humorous eye. Note her presentation of Mr. and Mrs. Bennet, for example. Their contrasting temperaments are first shown through their manner of conversation; Mrs. Bennet chatters on while Mr. Bennet counters her talk with mildly sarcastic statements, the mocking tone of which Mrs. Bennet completely misses. Jane Austen has been described as a feminist because of her portrayal of women in her novels. Pride and Prejudice has been the discussion of critics for many years. But more or less, her feminism relates to her 
background. During the Regency Period, women were not expected to maintain a life for themselves. They were influenced by their families to marry well in order to have a good future and be provided for.

There was a strong emphasis placed on money and class which is clearly evident in Pride and Prejudice. This style this novel, which some people refer to as feminism and others to the satirizing of women in this age of history. Austen could be described as a feminist in writing at all. But she wrote from her world and her womanly point of view. As she said on her own limitations, "I must keep to my own style and go on my own way; and though I may never succeed again in that I am convinced that I should totally fail in any other" (Dawson 1). She painted the world she knew. The absence of large passions and romance is absent from her pages because it was absent from her life. Her love life was said to be sad and strange. But she went on writing and provided 86 her audience with entertainment from her silly characters in Pride and Prejudice. Some of Austen s women were considered to be silly such as Mrs. Bennet and Lydia. Mrs. Bennet is described as a foolish, noisy woman whose only goal in life is to see her daughters married, and Lydia as gossipy, immature, and self-involved. But she also presented a variety of characters that she made fun of. On the male side, a prime example would be Mr. Collins, a pompous clergyman who seeks to inherit Mr. Bennet s property. But then of course there is Elizabeth who proves to be an admirable heroine who insists on being treated as a rational creature.

Through the character of Charlotte Lucas, Austen presents a rather cool and objective view of the limited options open to women. During the Regency Period, women did not receive the same offers of education that were offered to the gentlemen. They usually did not have careers and were expected to receive a practical training for their domestic role. One quote from a male stated that women should read neither poetry or politics--nothing but of books of piety and cookery. (Dawson1) The majority of girls time was spent on sewing and needlework. Throughout Pride and Prejudice, Elizabeth or Jane works on their cross-stitch during their leisure time. The household work though, was actually done by the servants. Mrs.Bennet prides herself on her family s being too genteel for her daughters to be involved in the cooking, unlike the Lucas family. Austen's novels have aroused intense emotional attachments among readers.

\section{Conclusion}

One admit to reading and re-reading her with the mouth open and and the mind close. Some readers carry admiration to the point of sentimental adoration; for them, her characters are beloved friends and Austen is dear Aunt Jane, a proper, sedate, 
kindly Victorian old maid. By virtue of a stronger personality and a keener sense of delicacy in art, she is a writer of the first rank. Jane Austen needs no testimonials; her position is at this moment established on a firmer basis than that of any of her contemporaries. She has completely distanced Miss Edgeworth, Miss Ferrier, Fanny Burney, and Hannah More,Writers who eclipsed her modest reputation in her own day. (Cornish 232). The miracle in Jane Austen's writing is not only that her presentment of each character is 87 complete and consistent, but also that every fact and particular situation is viewed in comprehensive proportion and relation to the rest.

\section{References}

[1] Dawson. Williams James. Jane Austen, and the Novel of Social Comedy. Fleming H. Revell Company, 1905

[2] Cornish, Francis Warre, English Men of Letters Jane Austen, St. Martin's Street, London: Macmillan,1913.

[3] Haggerty, Andrew. Jane Austen: Pride and Prejudice and Emma, Benchmark, New York: Marshall Cavendish, 2008 .

Ms. Nirupama Patel

Assistant Professor

Gandhinagar Institute of Technology, Gandhinagar 